\title{
TRANSLATING HIMACHALI FOLKTALES
}

\section{Sapna Dogra}

\begin{abstract}
Re-creation of the spirit of the original is the final and foremost test of any translator. Translation is a creative endeavour for those who succeed in reproducing the sense, rhythm, tone and emotions of the source language into the target language. Some of the fundamental problems of translation that occurred while translating folktales from Pahāri into English have been discussed in this paper and in the light of the discussion it can be said that translation is a creative and intelligent art that involves 'approximation' which is appropriate for the target culture. The approximation depends upon the interaction that lies between the story-tellers and the listeners. Translation of folktales is impossible if the story-teller (translator) does not understand the listeners (readers of the translated text) at the verbal, cultural, psychological and linguistic level. In order to explain this position, I would like to share my own experience as a translator of Himachali Folktales from Pahārī to English.
\end{abstract}

Key words: translation, folktales, Pahārị

The present paper is an outcome of my experience of translating Pahārī folktales. I translated them into English for the non- Pahärī readers. Since folktales are not associated with a particular author they tend to represent a populous view. Such anonymous arts run counter to those with an author function attached. The folktales I translated were taken from some wellknown anthologies and were published with a name of an 
author (collector and transcriber). The mode of the collection is not known; perhaps the tales came from memory. The tales were treated as mere variants. Many variants of the tales were available and the ones chosen for translation were selected at random.

Pahārī is a general term for various dialects spoken in the central Himalayan range. The word Pahārī is derived from the word 'Pahār' meaning 'mountain'. The term Pahārī means language of the mountain people. The term 'Western Pahari' given by Dr. Grierson is used collectively for the dialects spoken in Himachal Pradesh. ${ }^{1}$ K.S. Singh says:

Though a small state, there are as many as 32 languages spoken in Himachal Pradesh. Out of these there are 6 belonging to the Tibeto-Burman family, 3 unclassified, 2 are foreign and the remaining 21 to the Indo-Aryan and or its Pahari sub-family. (Foreword, xiii)

Nearly ninety percent of the people of Himachal Pradesh speak Western Pahārī. The main dialects of Pahārī language are: Sirmaurī, Mahāsūī, Kinnaurī, Kāngrī, Kēhlūrī, Sasōdhī, Gaddī, Bharmaurī, Lahaulī, Bhōțī, Kulūī, Mandiālī, Chambiālī, Baghāțī, Kēōnțhalī, Jaunsārī and Bhadērwāhī.

There is a unique similarity in the grammar, pronunciation and vocabulary of all the dialects, except for Lahauli and Kinnaurì. Pahärī in the past was written in Tänkarī script. But nowadays it is written in Devnägari script. The folktales I translated were also published in Devnāgari script. Owing to the similarity of various dialects, familiarity with just a few dialects was enough in helping with the translation.

Since English is the most widely understood language and the language I am most at ease with I decided to translate eight Pahārī folktales. The translation aimed at making these folktales reach out to a large audience in India in particular and the world in general. Such a work would become a means to make different 
speech communities know one another in a multi-lingual country like India. While translating, an attempt was made to stay close to the spirit of the original. The folktales translated may not exactly resemble the original oral rendition owing to loss of crude rustic humour in the course of translation; nevertheless, they expose the indigenous literature and mark a phase in history where it becomes imperative to introduce to others the literatures peculiar to a region.

\section{ROLE OF TRANSLATION}

The need for translation will continue to exist till there is a desire and curiosity to know other cultures. Translation then becomes a means by which different cultures can be made familiar and accessible to one another.

Translation is a form of communication. Translator takes the delightful pain to communicate and reproduce artistic expressions and stylistic specialities and features of a particular language. Every language has its own set of rhythms, rhymes, stock words, idioms, tone, proverbs and grammatical structures. Ideally, a good translation should produce the same effect on the receptor of the translated text as was produced on the original reader or listener and as Eugene A. Nida says, "The best translation does not sound like a translation." (12)

The need for translation arises because of infinite speech communities spread over the world speaking many independent and mutually incomprehensible languages. Each and every independent speech community is conditioned by its corresponding cultural heritage and linguistic systems. Faced with such a situation translation comes as a ready means and a boon for different speech communities to interact with one another and exchange ideas, views, thoughts and expressions that make their way into the world through a specific language. Had there been no translation we would have been bereft of great works like the Bible, The lliad, The Ramayana; great writers, philosophers 
and thinkers like Karl Marx, Leo Tolstoy Aristotle, Plato, Vladimir Nabakov, Rabindranath Tagore, to mention a few. It's a pity that translation suffers from having an unequal status when compared to the creative work.

When we use any language we also assume with it its culture. In translating Pahärī into English the search for the right equivalence is all the more challenging due to the different spheres of lexical and cultural experiences between source language (SL) and target language (TL). Translation is about equivalence. At its simplest translation may be defined as a replacement of text in one language with an equivalent text in another language. Finding an equivalent is the key requirement in the process. When one has to translate from Pahārī into English the formal changes were gargantuan, because the cultural context and different world views are so varied and diverse at both grammatical and lexical fronts that alterations, omissions, replacements and additions were required to preserve the content and create the desired effect.

Translation aims at a new readership. Any reader cannot be expected to master all or even a few languages of the world, and the experiences, culture and nuances associated with all the languages. It would have been amazing had there been a common language for all of us. But it is indeed a pity that not everyone in the world can communicate with one another for the lack of a common means of verbal expressions. In such a situation translation comes as a boon for reasons that could be political, intellectual, social, economic or any other. Translation establishes a link between several different cultures.

No folk text is either produced or received in vacuum, but is an integral part of a culture. Definite socio-cultural context governs the production and reception of any literary product. Various ideological positions govern and influence the way a text works in a society. Translation is the transfer of meaning from one language to another. In case of an oral narrative the 
original text is performance-based where the telling of the tales stands in the position of the original. Then recoding of the oral narrative into written text is a form of re-creation for another set of audience. The translator in such a situation is but another coauthor. The meaning that is transferred in translation is other than the denotative meaning or the literal 'sense'. It is the connotative meaning and the layers of meanings attached to the textual unit that are of major significance in the translation. Secondly, since translation is about finding the equivalent text, it becomes all the more difficult when translating literary text. Not much difficulty arises in non-literary translation. In translating the literary text, the retention of 'sense', 'significance', 'nuance' and 'connotation' is the primary objective. So the translation becomes an operation performed on two different linguistic systems (SL and TL), where the search for the right equivalence in the right place is all that is there to the art, craft and science of translation.

Translation plays a major role in evolution of literature in general and in expansion of a particular language (TL) in particular. Target language imbibes the creative aspects of the SL. Translation serves as a bridge between two cultures, by bringing people together and paving the way for an exchange of knowledge and creativity. Translation is that bridge by which people/reader pass from one language/culture/linguistic system to another. 'Works in translation' is an umbrella term that brings almost every literature and almost all readers together.

\section{Translation has been defined variously by different scholars thus:}

Nida and Taber says, "Translation consists in reproducing in the receptor language the closest natural equivalent of the source language message, first in terms of meaning and secondly in terms of style." (12)

J.C. Catford defines translation as, "The replacement of textual material in one language (SL) by equivalent textual 
Susan Bassnett says, "Translation involves the rendering of a source language (SL) text into a target language (TL) so as to ensure the surface meaning of the two will be preserved as closely as possible but not so clearly that the TL structures will be seriously distorted." (12)

Clearly, meaning and style cannot go together in a translation. The rustic linguistic flavour and humour associated with Pahārì language was difficult to reproduce; nonetheless it was the meaning that was of primary concern. In the process of translation part of the original meaning might be lost but the irreplaceable core was definitely retained.

In Translation as Discovery (1981) Sujit Mukherjee deals with various aspects of translation with reference to India and Indian English Literature. He regards 'Translation as Perjury', 'Translation as Patriotism,' 'Translation as Testimony", 'Translation as New Writing' and most interestingly 'Translation as Discovery'. The last aspect, 'Translation as Discovery' is the most applicable and interesting because there has always been a desire to let others 'discover' another literature through translation. Mukherjee says:

...element of discovery inherent in the making as well as in the reading of translation... English has made it possible for an Indian text to be read or 'discovered' in translation more widely than it could be in any other language earlier. . . Hence, though English may not be the most suitable language for translating Indian literary text, it offers the widest area of discovery through and in translation. (Preface)

Translator locates himself/herself in a space that lies between the two cultures and two different socio-linguistic factors. In literature, it becomes all the trickier because literature has no single but multiple layers of meanings (literal as well as 
metaphorical).

When translating from one Indian language into another, the problems faced by the translator are not as enormous as when translating from Indian language to English because of non-intimacy of cultures, language, syntax, idioms, etc. A false or defective translation can do more harm than good. The original work would be easily misunderstood if the translation is unintelligible.

The folktales are devoid of any artificiality in language, tone and narrative technique. The tales are simple, rustic and funny. Certain words, experiences, cultural institutions and phenomena that are absent in the English culture may still be recognised and understood in various parts of India. The rural set up of India and its corresponding cultural environment abounds with practices that are shared all over India. As H. Lakshmi says:

It is relatively easy to translate from one Indian language into another because here the culture is more or less the same. But translating from an Indian language into English is very difficult and problematic. For instance, in Indian languages we have honorifics indicative of the social distance between the speakers and the addressee but they do not have equivalents in English and hence create problems in translation. (14)

In translating from Pahārī into English language the search for ideal and perfect equivalence becomes challenging due to the cultural exclusivity between the SL and TL. Translator has to be doubly aware of the cultural context of both the SL and TL. Word to word translation failed to maintain the spirit of the original. The effect, emotion and the feeling of the original requires a lyrical and a poetical translation.

The basic requirement for any kind of translation is an indepth knowledge of the source culture as well as target culture. It requires a simultaneous understanding of the sense as well as the 
context. According to Mary Snell-Hornby"... the extent to which a text is translatable varies with the degree to which it is embedded in its own specific culture, also with the distance that separates the cultural background of source text and target audience in terms of time and place." (41) When translating the folktales, it was extremely difficult and challenging to do justice to the shades of humour which can remain intact only in the original language. Translation of syntactic, cultural and lexical problems faced while translating from Pahärī to English was a challenge in itself.

\section{PROBLEMATICS OF TRANSLATING Pahāṛī}

The eight folktales selected for translation were taken from the anthologies Ghāțiyān ri Gūnjān, Kathā Sarvarī Bhag-1, Himāchal Diyān Lōk-Kațhān, and journals Himbhärtī and Bāgar. The eight foktales are: Golden Pole (Sōnē rā Khūnḍa), Hanging the Grinding Mill (Ghrāte jō Phānsì), Five Bhallē (Panj Bhallē), As You Sow, So You Reap (Karṇiā dē Phal), Four Fools (Cār Mūrkh), Sharing the Divide (Bānḍchūnḍ), A Strange Heaven (Anōkhā Swarg), When I Wish to Have my Head Hit Again, Then! (Jadū Sirē Khūrk Hōngī Tān!). ${ }^{2}$

Since all the eight folktales chosen for translation are set in rural setting, it became imperative to retain some dialectical terms to avoid the tales from being read as mere abstracts of the original tales. Word like Tikkā, Kanwar, bhațūrū, Mahārāj, rajā sāhib, Ghrāțiyē, bhallē, karandūu, yūg, tamāśā, rōțī, khīnd and kismat were retained in order to preserve the regional grain and cultural specificity.

\section{Honorifics}

A wide network of honorific terms is an essential and non-translatable aspect of Indian society. The honorific terms like Mahārāj and rajā sāhib were retained in the target language because of the absence of its equivalents in the cultural setting of the TL. 


\section{Agrarian Items}

The tale Sharing the Divide is set in a village. The entire story is in the form of conversation. The original khind was retained to indicate the rural backdrop with its peculiar socio-economic set up. The word khind could have been translated as:

(a) quilt (literal meaning in English)

(b) to explain it as crude quilt made of old worn out clothes

(c) cheap blanket

The first option and third option was ruled out in order to give a true representation of rural setting. Quilt and blankets are used by everyone irrespective of class. The second option is too long an explanation to be inserted in the text itself. Hence the original khind was retained with some information in the text itself and a longer and appropriate footnote was given for a detailed explanation.

Just like khind the word karandu (bamboo basket) in the tale Five Bhalle was also retained because it reminds the readers of the agrarian set up of the tale and the socio-economic motifs of the tales gets repeatedly asserted. The above terms are culture specific and prevalent in Himachal Pradesh.

\section{Titles of The Folktales}

In the tale When I Wish to Have My Head Hit Again, Then! the translation of idiomatic title itself was a problem. The original title in Pahārī was: Jadū Sirē Khūrkh Hōngì Tān!

Jadū Sirē Khūrkh Hōngī Tān

when head itch happen then

Now the option of literal translation was completely ruled out 
because it would not make any sense to the readers and the tale would not have been worth enjoying; such sentence structure seemed awkward in English. So the option retained evokes the same response in English that Pahärī language had produced on the original readers. Such idiomatic expressions posed a challenge to the translator because the intention and interpretation are complicated and subtle.

Similarly, the title of the tale Sharing the Divide in original was Bānḍchūnd, in Hindi 'banțwārā' which literally means 'division' but in Indian context it is more of a division of property.

\section{The word bānḍchūnḍ could have been translated as:}

(a) division

(b) partition

Both the options were ruled out as they were unable to do justice to the original term. Familial property requires sharing as well as dividing. Hence'Sharing the Divide' was thought to be appropriate.

\section{Allegorical Names}

In Golden Pole the words like yūg, Kaliyūg, Satyūg, Dwāparyūg and Tretāyūg were retained as it is because no English words can do justice to the systems of yūg (eras) that are the very basis of Hindu belief system. In fact, the word hawā in original which means 'wind' was given the Sanskrit rendering Vāyū to keep consistency in the names of allegorical characters. Mere 'wind' would mean an element of nature but here the wind is an allegorical character. Such words are loaded with cultural significance. It was felt that nothing in English can bring out the cultural undertones of these words and expressions.

\section{Food Items}

Words like bhallē and bhațūrū are not just dishes but are 
the carriers of Pahärī culture. Words like cakes and pies could also have done the work but since the tales itself revolve around the food items it becomes imperative to retain the original as an index of Pahārī culture and sensibilities.

\section{Names as Identity Markers}

In Hanging the Grinding Mill, the word Tikkā and Kanwar were retained because they are the identity markers and carriers of a social position in Pahārī society. Similarly, the name Ghrātiyē is very popular in Himachal Pradesh for the owner of grinding mills.

In the tale Sharing the Divide, the names of the two brothers were 'Sulkhanū and 'Kulkhaṇū' which would roughly mean the good boy and the bad boy, respectively. Since the very names serve as a mirror for their characters the names 'Goody' and 'Baddy' served the purpose for the translation.

\section{Derogatory Terms}

Every language is insidiously tied up with emotions and cultural nuances. Emotions are difficult to translate. Every language has its set of stock words, derogatory words, curses, oaths and slangs. Especially in a colloquial rural set-up one can expect and observe a frequent use of such terms.

The word rānd would translate as 'whore'. But the feeling behind the word has to be given consideration. In Five Bhalle the word is used in an affectionate way and there is no expression of cruelty or callousness, nor is it used in its abusive connotation; whereas in As You Sow, So You Reap it has the connotation of curse, hatred and utter dislike for the lady to whom it is directed. Words like this cannot be judged merely as words of abuse. Their meaning has to be extracted from the context. Words charged with connotations cannot be substituted for a neat parallel version of TL. 


\section{Others}

The words like tamāśā and kismat were also retained. Tamāśá means not just a spectacle but a drama with a performative aspect in focus. Kismat is one of the most frequently used terms in day to day conversations in India. The term asserts the belief in destiny and karmā.

\section{Rustic Humour}

Greatest problem was that of sustaining the crude, colloquial humour that is inherent in Pahärī language in general. Humour is blended with the texture of Pahärī language. Recreation of the spirit of the original is the final and foremost test of any translator. Translation is a creative endeavour for those who succeed in reproducing the sense, rhythm, tone and emotions of the SL into the TL. The art lies in creative re-telling of the original.

\section{Narrative Style}

The narrative style of the tales is very simple. There is a consistent use of short sentences and lack of long, complex and compound sentences. The content and the style are natural devoid of any artificiality.

Gautam Sharma 'Vyathit' says about the narrative style of the Pahārī folktales:

The method of narration in Himachal Pradesh is very interesting tool. For hours the listeners sit enthralled by the art of the narrator and the intricacy of the tales. They must constantly intersperse the narrative with'Huni'(Yes, go on) so that the narrator is sure of holding their attention, and is spurred to generate flights of fancy by the active admiration of his audience. (133)

Foremost difficulty was in retaining the music and rhythm of narration in translation. Translation demands creative imagination just like original writing. In fact, the translator's task is 
more difficult as he/she has to capture and convey the essence of the heart and mind of another individual. The translator's ultimate challenge lies in carefully transmitting the soul of the original work into the target language without damaging the structure, meaning or beauty of the original text or the source and target languages.

\section{Conclusion}

Some of the fundamental problems of translation that occurred while translating folk texts from Pahārī into English have been discussed and in the light of the discussion it can be said that translation is a creative and intelligent art that involves 'approximation' which is appropriate for the target culture. The approximation depends upon the interaction that lies between the story-tellers and the listeners. Translation of folktales is impossible if the story-teller (translator) does not understand the listeners (readers of the translated text) at the verbal, cultural, psychological and linguistic level. Translation is variously referred to as art, science and craft. But it is judged to be more than all these. Translation cannot be governed by any rules. It is a way of establishing contacts between cultures. Translation is a work of intelligent interpretation, creative writing and co-creation.

\section{NOTES}

${ }^{1}$ For a detailed study of Pahärị language see:

a. Singh, Mian Goverdhan. 1988. Himachal Pradesh: History Culture and Economy. Shimla: Minerva Book House.

b. Singh, K.S. 1996. People of India Ed. B.R. Sharma and A.R. Sankhyan. Vol. 3. Anthropological Survey of India: Manohar Publishers.

c. Parmar, Y.S. 1970. Himachal Pradesh: Area and Language. Himachal Pradesh: Directorate of Public Relations, H.P. Government. 
${ }^{2}$ The source of the eight folktales is as follows:

a. Five Bhallē (Pānj Bhallē) by Dinesh Kumar Sharma in Bägar: Lōk-Kathā Viśéśānk, Oct.-Dec.1995/Jan.-March 1996, p. 31.

b. Four Fools (Cār Mūrkh) by Devraj Sharma in Ghāțiyān rī Gūnjān: Himāchal Lōk-Kathā Sangrēh Bhag-1. Bilaspur (H.P.): Kiran Book Depot, 1974. p. 131-32.

c. Golden Pole (Sōnē rā Khūnḍā) by Subhashna Devi in Himbhārti (Lōk-Kathā Viśéśānk). Himachal Kala, Sanskriti Bhasha Academy, Shimla. Jan.-June, 1999. p. 40-41.

d. Hanging the Grinding Mill (Ghrātēēō Phānsī) by Sansarchand Prabhakar in Himbhārti (Lōk-Kathā Viśessānk). Himachal Kala, Sanskriti Bhasha Academy, Shimla. Jan.-June, 1999. p. 2425.

e. Sharing the Divide (Bänḍūnd) by Moti Lal Ghai in Bāgar: Lōk-Kathā Viśéśänk, Oct.-Dec.1995/Jan.-March 1996. p. 22.

f. Strange Heaven (Anōkhā Swarg) by Thakur Dutta Sharma in Kathā Sarvarī. Bhag-1. Himachal Kala, Sanskriti Bhasha Academy, Shimla. Jan. 1977. p. 48-49.

g. When I Desire to Have my Head Hit Again, Then! (Jadū Sirē Khūrk Hōngī Tān!). by Guleri Bandhu in Himāchal Dìyān LōkKathān. Dharamshala (H.P.): Kirti Kusum Prakashan, 2002. p. 24-26.

h. As You Sow, So You Reap (Karniā de Phal) by H. Kapila in Bāgar: Lōk-Kathā Viśéśānk, Oct.-Dec.1995/Jan.-March 1996. p. 84.

\section{REFERENCES}

- Bassnett-McGuire, Susan. 1988. Translation Studies. London: Routledge. 
- Catford, J.C. 1965. A Linguistic Theory of Translation. London: OUP.

- Grierson, George Abraham . 1903-1928. Linguistic Survey of India. Calcutta Supt., Govt. Printing.

- Lakshmi, H.1993. Problems of Translation (English and Telegu): A Study of Literary and Technical Texts. Hyderabad: Booklinks Corporation.

- Mian Goverdhan Singh. 1988. Himachal Pradesh: History Culture and Economy. Shimla: Minerva Book House.

- Mukherjee, Sujit. 1981. Translation as Discovery: And Other Essays on Indian Literature in English Translation. New Delhi: Allied Publishers Private Limited.

- Nida, Eugene, A., and Taber, Charles T. R. 1982. The Theory and Practice of Translation. USA: United Bible Societies.

- Parmar, Y.S. 1970. Himachal Pradesh: Area and Language. Himachal Pradesh: Directorate of Public Relations, H.P. Government.

- Sharma, Gautam.1984. Folklore of Himachal Pradesh. Trans. Mrinal Pande. New Delhi: National Book Trust of India.

- $\quad$ Singh, K.S. 1996. People of India Ed. B.R. Sharma and A.R. Sankhyan. Vol. 3. Anthropological Survey of India: Manohar Publishers.

- Snell-Hornby, Mary. 1988. Translation Studies: An Integrated Approach. Amsterdan/PIphia: John Benjamins Publishing Company. 